\title{
PENGARUH KESEJAHTERAAN GURU, MOTIVASI KERJA DAN KOMPETENSI GURU TERHADAP KINERJA GURU SMK DI KABUPATEN SUMBA BARAT
}

\author{
Samuel Kali Kulla \\ Program Studi Manajemen Pendidikan Pasca Sarjana Unesa \\ samskulla@gmail.com
}

\begin{abstract}
Teachers play an important role in creating human resource education that are reliable so it requires teachers to have good performance. This study aimed to analyze the influence of teachers' welfare, motivation and competence of teachers together and partially on the performance teachers in West Sumba. This study included a correlational study with a quantitative approach, using proportional sampling and analysis by multiple regression analysis. Based on the results of research can be concluded that there is influence of teacher competence partially on the performance of teachers and simultaneously influence the welfare of teachers, motivation, competence of teachers on the performance teachers in West Sumba. Efforts to improve the welfare of teachers, motivation and competencies teachers need to do together to improve the performance of teachers.
\end{abstract}

Keywords : Teachers Welfare, Motivation, Teachers Competence, Teacher Performance

Abstrak: Guru memegang peranan penting dalam menciptakan sumber daya manusia pendidikan yang handal sehingga diperlukan guru yang memiliki kinerja baik. Penelitian ini bertujuan untuk menganalisis pengaruh kesejahteraan guru, motivasi kerja dan kompetensi guru secara bersama-sama dan parsial terhadap kinerja guru SMK di Kabupaten Sumba Barat. Penelitian ini termasuk penelitian korelasional dengan pendekatan kuantitatif, penarikan sampel menggunakan Proportional Sampling dan Analisis data dengan Analisis regresi berganda. Berdasarkan hasil penelitian dan pembahasan dapat disimpulkan bahwa terdapat pengaruh kompetensi guru secara parsial terhadap kinerja guru dan pengaruh secara simultan antara kesejahteraan guru, motivasi kerja, kompetensi guru terhadap kinerja guru SMK di Kabupaten Sumba Barat. Upaya meningkatkan kesejahteraan guru, motivasi kerja dan kompetensi guru perlu dilakukan secara bersama-sama dalam meningkatkan kinerja guru

Kata kunci : Kesejahteraan Guru, Motivasi, Kompetensi Guru, Kinerja Guru. 
Pendidikan merupakan sarana penting dalam mengembangkan sumber daya manusia (SDM) dan watak bangsa (Nation Character Building), karena harkat dan martabat suatu bangsa sangat ditentukan oleh mutu pendidikannya. Menurut Undang-Undang Sisdiknas Nomor 20 tahun 2003 tentang Sistem Pendidikan Nasional pendidikan bahwa pendidikan adalah usaha sadar dan terencana untuk mewujudkan suasana belajar dan proses pembelajaran agar peserta didik secara aktif mengembangkan potensi dirinya untuk memiliki kekuatan spiritual keagamaan, pengendalian diri, kepribadian, kecerdasan, akhlak mulia, serta keterampilan yang diperlukan dirinya, masyarakat bangsa dan negara. Salah satu sumber pendidikan adalah guru. Mengingat peran guru yang sedemikian pentingnya dalam menciptakan sumber daya manusia pendidikan yang handal maka sangatlah diperlukan guru yang memiliki kinerja baik.

Menurut pasal 10 ayat 1 Undang-Undang Republik Indonesia No. 14 tahun 2005 tentang Guru dan Dosen, dan Peraturan Pemerintah Republik Indonesia No. 74 tahun 2008 tentang Guru dalam pasal 3 ayat (2) menyebutkan bahwa: kompetensi guru meliputi kompetensi pedagogik, kompetensi kepribadian, kompetensi sosial, dan kompetensi profesional yang diperoleh melalui pendidikan profesi. Semua kompetensi di atas harus tampak pada dokumen kurikulum (curriculum plan) yang berisi serangkaian mata pelajaran, silabus dan materi ajar, dan program kegiatan pembalajaran yang strategis dan skenarionya disusun dalam rencana pembelajaran (Sagala, 2009:158).

Berdasarkan penjabaran di atas dapat dikatakan bahwa untuk menilai kompetensi guru dapat diamati dari dokumen pembelajaran yang dibuat oleh guru yang besangkutan. Dokumen pembelajaran dimaksud dibuat dalam bentuk Rencana Pelaksanaan Pembelajaran (RPP).

Kinerja merupakan gabungan dari tiga faktor yang terdiri dari (a) pengetahuan, khususnya yang berhubungan dengan pekerjaan yang menjadi tanggung jawab atau lamanya bekerja,(b) pengalaman, tidak sekedar berarti jumlah waktu atau lamanya bekerja, tetapi berkenaan juga dengan substansi yang dikerjakan, (c) kepribadian, berupa kondisi di dalam diri seseorang dalam menghadapi bidang kerjanya, seperti minat, bakat, motivasi kerja, dan disiplin kerja (Nawawi, 2006:64-65). "Young people are motivated to teach not by only one motive but by many reasons such as working conditions, being in service to people, appropriateness to personality, salary, social status and prestige, appointment, etc" (Yu, 2013)

Tugas keprofesian guru menurut Undang-Undang No.14 Tahun 2005 tentang Guru dan Dosen pasal 20(a) adalah: merencanakan pembelajaran, melaksanakan proses pembelajaran dan mengevalasi hasil pembelajaran.

Beberapa faktor yang mempengaruhi kinerja guru, di antaranya adalah kesejahteraan, motivasi kerja dan kompetensi. khususnya yang berhubungan dengan pekerjaan yang menjadi tanggung jawab atau lamanya bekerja,(b) pengalaman, tidak sekedar berarti jumlah waktu atau lamanya bekerja, tetapi berkenaan juga dengan substansi yang dikerjakan, (c) kepribadian, berupa kondisi di dalam diri seseorang dalam menghadapi bidang kerjanya, seperti minat, bakat, motivasi kerja, dan disiplin kerja (Nawawi, 2006:64-65).

Berdasarkan data yang diperoleh dari Dinas Pendidikan Pemuda dan Olah Raga Kabupaten Sumba Barat bahwa jumlah guru SMK dikabupaten Sumba Barat adalah 257 orang guru. Dari jumlah tersebut yang telah mendapatkan tunjangan profesi guru (TPG) adalah sebanyak 64 orang guru dan yang mendapatkan tunjangan daerah terpencil sebanyak 7 orang guru. Masih terdapat 193 orang guru SMK yang belum tersertifikasi. Dari 257 guru SMK yang ada 98 di antaranya adalah guru non PNS dengan status sebagai guru kontrak daerah yang setiap bulannya diberi upah senilai Rp.1.250.000., sebuah penghasilan yang boleh dikatakan sangat 
kecil jika dibandingkan dengan tuntutan hidup saat ini.

Data diatas menunjukkan 193 (75\%) guru belum menerima tunjangan profesi guru (TPG) dan gaji guru kontrak yang sangat tidak memadai sehingga diduga adanya beberapa dari guru SMK di Kabupaten Sumba Barat yang kesejahteraannya masih belum sesuai dengan harapan. Dampak dari kesejahteraan guru yang kurang memadai ini terlihat dari masih banyaknya guru yang melaksanakan pekerjaan tambahan lain disamping tugas utamanya dalam mengajar yaitu mengajar pada beberapa sekolah, berdagang kecilkecilan di lingkungan sekolah, maupun beternak, yang mana hal-hal tersebut akhirnya akan berdampak pada kinerja guru.

Dalam hal motivasi kerja ada kecendrungan sejumah guru memiliki motivasi kerja yang rendah hal ini dapat terpantau dari keterlambatan guru dalam bekerja, masih seringnya diketemukan kelas yang kosong saat jam pelajaran berlangsung dan laporan-laporan kerja yang tidak sesuai dengan jadwal serta hal-hal lainnya yang dirasa kurang optimal. "Teachers' ideas are strongly influenced by feedback from other stakeholders in educational practice: colleagues, administrators and trainees" (Roermund, Tromp, Scherpbier, Bottema, \& Bueving, 2011).

Selain fenomena tersebut di atas, juga terdapat guru dengan motivasi kerja guru cukup baik hal ini terlihat dari tanggung jawab guru dalam melaksanakan tugas dan tanggung jawabnya di sekolah yang walaupun dengan kondisi wilayah yang cukup sulit dengan jarak jangkauan sekolah ke pusat kota berkisar antara 12-60 KM. Motivasi kerja seorang guru akan dipengaruhi oleh berbagai faktor internal dan faktor eksternal. Faktor internal antara lain prestasi, pengakuan/penghargaan, tanggung jawab, memperoleh kemajuan dan perkembangan dalam bekerja. Sedangkan faktor eksternal antara lain gaji/upah, hubungan antara pekerja, supervisi teknis, kondisi kerja, kebijaksanaan lembaga/sekolah, dan proses administrasi sekolah (Herzberg dalam Nawawi, 2003 : 354). Selain itu "classroom self-efficacy and relationship satisfaction play a key influencing role in the relationships between the indicators"(Canrinus \& Helms-lorenz, 2012).

Pada dasarnya upaya peningkatan mutu pendidikan sangat dipengaruhi oleh tingkat komitmen dan profesionalitas guru dalam melaksanakan tugas pokoknya di sekolah (Philip, 2013). Dewasa ini lingkungan social mengambil peran yang sangat besar (Bok et al., 2013). Terdapat beberapa hal yang mempengaruhi kinerja guru antara lain guru, siswa, sarana dan prasarana, lingkungan pendidikan, serta kurikulum (Djatmiko, 2006). Kinerja adalah aktivitas seseorang dalam melaksanakan tugas pokok yang dibebankan kepadanya. Mengacu dari pandangan ini dapat diinterpretasikan bahwa kinerja seseorang dihubungkan dengan tugas-tugas rutin yang dikerjakannya (Uno dan Lamatenggo, 2015:60). "Based on theories on interpersonal relationships, it is postulated that teachers have a basic need for relatedness with the students in their class" (Spilt, Koomen, \& Thijs, 2011). Menurut Withmore (Uno dan Lamatenggo 2015: 59), kinerja adalah suatu perbuatan, suatu prestasi, atau apa yang diperlihatkan seseorang melalui keterampilan yang nyata. Berdasarkan pandangan Withmore ini , kinerja menuntut adanya pengekspresian potensi seseorang, dan tanggung jawab/kepemilikan yang menyeluruh. "Mission statement set up long term strategy of an institution" (Rotthoff et al., 2012). Guru memiliki peran strategis dalam bidang pendidikan, bahkan sumber daya pendidikan lain yang memadai sering kali kurang berarti apabila tidak didukung oleh guru yang berkualitas, dan begitu juga sebaliknya (Djatmiko, 2006). "Teachers are key actors who shape the learning environment and whose main tasks include motivating students to learn." (Hornstra, Mansfield, \& Veen, 2015).

Berkaitan dengan kinerja guru, wujud perilaku yang dimaksud adalah kegiatan guru dalam proses pembelajaran yaitu 
bagaimana seorang guru mecencanakan pembelajaran, melaksanakan kegiatan pembelajaran, dan menilai hasil belajar. Kinerja guru adalah kemampuan dan usaha guru untuk melaksanakan tugas pembelajaran sebaikbaiknya dalam perencanaan program pengajaran, pelaksanaan kegiatan pembelajaran dan evaluasi hasil pembelajaran (Dharma, 2008:20).

Kesejahteraan dalam kamus lengkap bahasa Indonesia diartikan sebagai suatu keadaan sejahtera, keamanan, keselamatan, ketentraman, kemakmuran, kesenangan hidup dan sebagainya. Sementara dalam buku pengantar Studi Kesejahteraan Sosial Lombok Barat dijelaskan bahwa kesejahteraan merupakan suatu kondisi/keadaan yang sejahtera baik fisik, mental, maupun social. "This rising interest made me wonder where teachers and teaching practice fit in the concept of a learning environment." (Sullivan, 2015). Menurut Tafqihan terdapat terdapat pengaruh positif kompetensi terhadap kinerja guru (Tafqihan, 2014). Terdapat pengaruh yang signifikan pemberian kompensasi guru terhadap kinerja guru (Karo, 2013). Namun di sisin lain guru yang sudah lulus sertifikasi dan sudah menerima tunjangan belum seluruhnya berkinerja tinggi (Soewarno \& Fitri, n.d.). sebagaimana dalam penelitian Khodijah bahwa tidak terdapat perbedaan dalam kinerja guru setelah menerima tunjangan professional (Khodijah, 2009). Bahkan terdapat perubahan sosial dan ekonomi yang terjadi pada guru yang telah mendapatkan tunjangan profesi guru, berupa perubahan dalam mengkonsumsi makanan, cara berpakaian, hobi/hiburan, bacaan sering dibaca, pergaulan, pekerjaan sampingan, fasilitas hidup guru, pengelolaan penghasilan, peran serta dalam organisasai dan hubungan suami istri dan anak (Purwanto, 2012).

Kesejahteraan guru adalah pemberian kemakmuran hidup kepada orang yang bekerja di lingkungan pendidikan, baik yang berupa material maupun spiritual sehingga terpenuhi kehidupan yang layak dan lebih baik sebagai timbal balik atau balas jasa dari tanggung jawab yang dipikulnya. "The crucial role of teachers for positive learning outcomes is strongly acknowledged in the teacher effectiveness research tradition as well'(Maulana, Yulia, \& Wim, 2016). Pemenuhan kesejahteraan yang memadai bagi guru akan menambah semangat dalam pekerjaannya, sehingga timbul kesadaran untuk mengembangkan dan meningkakan kualitas sumber daya yang ada pada dirinya ( Samana,1994:15). Terdapat beberapa istilah yang digunakan untuk menyebut gaji guru, antara lain: compensation, remuneration, and salary (Li, 2014). Gaji adalah balas jasa dalam bentuk uang yang diterima pegawai sebagai konsekuensi dari kedudukannya sebagai seorang pegawai yang memberikan sumbangan dalam mencapai tujuan organisasi (Yusta \& Pradata, 2015). Peningkatan kemampuan profesional guru merupakan kegiatan yang terintegrasi dengan kegiatan pembelajaran di sekolah, satu sisi mampu meningkatkan kualitas mengajar mereka sebagai guru, di sisi lain dapat memberi peluang bagi mereka meningkatkan kemampuan professional (Cahyana, 2006).

Surya (2003:167), mengatakan bahwa guru yang dianggap sejahtera adalah mereka yang melaksanakan tugasnya sebagai tenaga profesional, dan memiliki kepuasan terhadap kinerjanya. Adapun indikator kesejahteran guru adalah :

a. Imbalan jasa

Imbalan jasa merupakan salah satu faktor penentu kesejahteraan guru atau karyawan.Imbalan jasa biasa diberikan setelah melakukan sesuatu pekerjaaan, atau dapat dikatakan sebagai upah atas suatu pekerjaan yang dilakukan seseorang.

Selain itu sebagai wujud nyata kepedulian pemerintah atas kejahteraan guru telah diterbitkannnya Undang-Undang No.14 Tahun 2005 tentang guru dan dosen yang salah satu diantaranya mengenai tunjangan profesi guru (TPG). 
b. Hubungan Kerja

Keamanan dan kenyamanan guru dalam melaksanakan tugas dan tanggung jawabnya ditentukan salah satunya oleh hubungan/relasi yang terjadi dalam lingkungan tempat bekerja. Hubungan yang positif dan harmonis yang terjalin diantara guru dan semua elemen pendikan (kepala sekolah, sesama guru, TU, siswa dan wali murid) merupakan faktor pendukung kesejahteraan guru.

\section{c. Rasa Aman}

Situasi dan kondisi lingkungan tempat kerja yang aman sangat diperlukan seorang guru untuk dapat melaksanakan tugasnya dengan baik. Jika lingkungan tempat bekerja tidak menjamin keamanan guru maka berbagai hal dapat saja terjadi misalnya guru kurang bersemangat dan takut untuk bekerja.

d. Kesempatan untuk pengembangan dan peningkatan diri

Pelatihan adalah suatu kegiatan untuk meningkatkan kemampuan intelektual termasuk pengetahuan, penguasaan, penerapan dan pengembangan ilmu pengetahuan dan tehnologi para guru yang akan berdampak pada peningkatan komptensi dan kinerja guru.

Motivasi merupakan dorongan yang terdapat dalam diri seseorang unuk berusaha mengadakan perubahan tingkahlaku yang lebih baik dalam memenuhi kebutuhannya (Uno, 2015). Dorongan tersebut didasrkan pada kebutuhan sesuai teori Maslow yaitu terdiri dari 5 kebutuhan (1) Kebutuhan fisiologis, (2) Kebutuhan rasa aman, (3) Kebutuhan cinta kasih (4) Kebutuhan pengharagaan (5) Kebutuhan aktualisasi diri)

Kompetensi guru merupakan perpaduan antara kemampuan personal, keilmuan, teknologi, sosial, dan spiritual yang secara keseluruhan membentuk kompetensi standar profesi guru, yang mencakup penguasaan materi, pemahaman terhadap peserta didik, pembelajaran yang mendidik, pengembangan pribadi dan profesionalisme (Mulyasa, 2009). Kompetensi Pedagogik adalah kompetensi cara-cara mendidik peserta didik (Pidarta, 2007). Wujud dari kompetensi pedagogik ini harus tampak pada dokumen kurikulum ( curriculum plan) yang bersisi serangkaian mata pelajaran, silabus dan materi ajar, dan program kegiatan pembelajaran yang strategi dan skenarionya disusun dalam rencana pembelajaran (Sagala, 2009:158).

Berdasarkan kajian yang berkaitan dengan Kesejahteraan guru, Motivasi kerja dan Kompetensi Guru terhadap Kinerja Guru, maka diambil hipotesis sebagai berikut :

1. Terdapat pengaruh kesejahteraan guru terhadap kinerja guru SMK di Kabupaten Sumba Barat.

2. Terdapat pengaruh motivasi kerja terhadap kinerja guru SMK di Kabupaten Sumba Barat.

3. Terdapat pengaruh kompetensi guru terhadap kinerja guru SMK di Kabupaten Sumba Barat.

4. Terdapat pengaruh secara simultan/bersama-sama antara kesejahteraan guru, motivasi kerja dan kompetensi guru terhadap kinerja guru SMK di Kabupaten Sumba Barat.

\section{METODE}

Pendekatan yang digunakan dalam penelitian ini adalah pendekatan kuantitatif. Pendekatan kuantitatif digunakan untuk mengetahui korelasi antara variabel bebas denga variabel kesejahteraan guru, motivasi kerja dan kompetensi guru terhadap kinerja guru SMK di Kabupaten Sumba Barat. Jenis penelitian yang yang digunakan adalah penelitian korelasional yang penelitian yang bertujuan untuk menguji dan mengungkapkan pengaruh antara variabel bebas terhadap variabel terikat.

Adapun disaen penelitian seperti gambar berikut ini : 


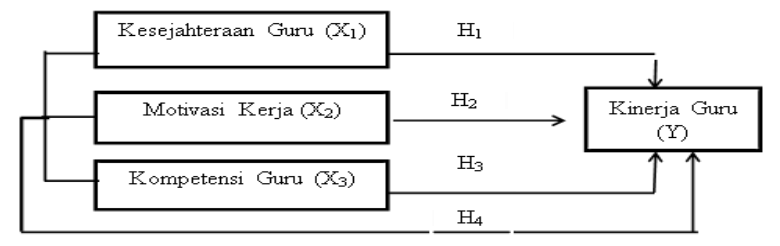

Gambar 1 Rancangan Penelitian Regresi Linier Berganda

Keterangan :

$\mathrm{H}_{1}=$ Pengaruh $\mathrm{X}_{1}$ terhadap $\mathrm{Y}$ secara sendiri

$\mathrm{H}_{2}=$ Pengaruh $X_{2}$ terhadap $Y$ secara sendiri

$\mathrm{H}_{3}=$ Pengaruh $X_{3}$ terhadap $Y$ secara sendiri

$\mathrm{H}_{4}=$ Pengaruh $\mathrm{X}_{1}, \mathrm{X}_{2}, \mathrm{X}_{3}$, dan $\mathrm{X}_{4}$ terhadap $\mathrm{Y}$ secara bersama-sama

Adapun variabel penelitian ini adalah sebagai berikut :

1. Variabel Bebas (independent variable)

Kesejahteraan $\mathbf{G u r u}\left(\mathbf{X}_{\mathbf{1}}\right)$. Pendekatan yang digunakan pada variabel kesejahteraan guru $\left(\mathrm{X}_{1}\right)$ untuk mendapatkan data dengan cara melakukan pemberian skor pada setiap indikator dimensi yang ada yaitu (a) imbalan jasa, (b) rasa aman, (c) hubungan antar pribadi (d) kesempatan untuk pengembangan dan peningkatan diri

Motivasi kerja $\left(\mathbf{X}_{2}\right)$.Pendekatan yang digunakan pada variable motivasi guru $\left(\mathrm{X}_{2}\right)$ untuk mendapatkan data dengan cara melakukan pemberian skor kepada setiap indikator dari dimensi yang ada yaitu : ( a)
Tanggung jawab,
(b) Prestasi,

Pengembangan Diri, (d) Kemandirian

Kompetensi Guru $\left(\mathbf{X}_{3}\right)$. Pendekatan yang digunakan pada variable kompetensi guru $\left(\mathrm{X}_{1}\right)$ untuk mendapatkan data dengan cara melakukan pemberian skor pada setiap indikator komponen dimensi kompetensi pedagogik guru dalam pembuatan dokumen pembelajaran dam bentuk Rencana Pelaksanaan Pembelajaran (RPP) dengan komponennya sebagai berikut : (1) Tujuan Pembelajaran, (2) Bahan Ajar, (3) Strategi/metode pembelajaran , (4) Media Pembelajaran, (5) Evaluasi hasil belajar

2. Variabel Terikat (dependent variable)

Pendekatan yang digunakan pada variable kinerja guru "adakah Pengaruh" untuk mendapatkan data dengan cara melakukan pemberian skor pada setiap indikator dimensi kinerja guru yang terwujud dalam bentuk kegiatan (a) merencanakan proses pembelajaran, (b) melaksanakan proses pembelajaran (c) mengevaluasi hasil pembelajaran

Populasi dalam penelitian ini adalah sema guru SMK di Kabupaten Sumba Barat tahun 2017 sebanya 257 orang guru. Teknik penarikan sampel dalam penelitian ini menggunakan Proportional Sampling berdasarkan pendapat Arikunto (2010) yaitu berkisar antara 10-25\% dari pupulasi.Jumlh sampel dalam penelitian ini adalah 65 responden.

Pengumpulan data penelitian menggunakan metode angket/kuesioner, dokumentasi dan observasi.

\section{HASIL}

\section{Hasil Uji Validitas Instrumen}

Variabel Kesejahteraan Guru $\left(\mathrm{X}_{1}\right)$

Berdasarkan nilai hasil uji validitas variabel Kesejahteraan Guru di atas diketahui bahwa seluruh item pernyataan mengenai variabel kesejahteraan guru dinyatakan valid dan dapat digunakan sebagai alat penelitian kerena memiliki nilai signifikansi lebih kecil dari 0.05 .

Berdasarkan nilai hasil uji validitas variabel Motivasi Kerja di atas diketahui bahwa seluruh item pernyataan mengenai variabel motivasi kerja dinyatakan valid dan dapat digunakan sebagai alat penelitian karena memiliki nilai signifikansi lebih kecil dari 0.05 .

\section{Hasil Uji Reliabilitas}

Menurut Nugroho (2005:114) reliabilitas suatu konstruk variabel dikatakan baik jika nilai Alpha Cronbach $>0,60$. Nilai reliabilitas kontruksi internal, untuk koofisien alpha masing-masing variabel Kesejahteraan Guru $\left(\mathrm{X}_{1}\right)$ dan Motivasi kerja $\left(\mathrm{X}_{2}\right)$ dinyatakan reliabel karena memiliki nilai Cronbach Alpha lebih besar dari 0,60. Dengan demikian instumen variabel kesejahteraan guru dan 
motivasi kerja dinyatakan reliabel dan dapat digunakan dalam penelitian ini.

\section{Deskripsi Variabel Penelitian}

Dapat diketahui bahwa pada indikator imbalan jasa memiliki nilai rata-rata sebesar 2,58 dikatergorikan mempunyai nilai baik, indikator rasa aman yang peroleh guru dalam lingkungan kerja mempunyai nilai sebesar 2,78 yang dikategorikan baik, pada indikator hubungan antar pribadi memiliki nilai rata-rata sebesar 2,88 dengan katergori baik, dan indikator kesempatan pengembangan dan peningkatan diri dengan nilai sebesar 2,59 dengan kategori baik. Berdasarkan deskripsi kategori nilai indikator variabel kesejahteraan guru di atas dapat disimpulkan bahwa indikator yang paling dominan dalam variabel kesejahteraan guru adalah indikator hubungan antar pribadi karena memiliki skor nilai yang sangat tinggi yaitu 2,88. Secara umum kesejahteraan guru memiliki nilai rata-rata sebesar 2,71 dengan kategori baik.

\section{Variabel Motivasi Kerja}

Dapat diketahui bahwa pada indikator tanggung jawab memiliki nilai rata-rata sebesar 3,25 dikatergorikan mempunyai nilai tinggi/baik, indikator prestasi mempunyai nilai sebesar 3,27 yang dikategorikan sangat tinggi/sangat baik, dan indikator kemandirian memiliki nilai rata-rata sebesar 3,29 dengan katergori sangat tinggi / sangat baik . Berdasarkan deskripsi kategori nilai indikator variabel motivasi kerja di atas dapat disimpulkan bahwa indikator yang paling dominan dalam variabel motivasi kerja adalah kemandirian karena memiliki skor nilai yang sangat tinggi yaitu 3,29 . Secara keseluruhan motivasi kerja mempunyai nilai rata-rata sebesar 3,26 dengan kategori sangat tinggi/sangat baik.

\section{Variabel Kompetensi Guru}

Dapat diketahui bahwa pada indikator tujuan pembelajaran memiliki nilai rata-rata sebesar $71,5 \%$ dikatergorikan mempunyai baik, indikator bahan ajar/ materi pelajaran mempunyai nilai sebesar $70,0 \%$ yang dikategorikan baik, indikator strategi/metode pembelajaran mempunyai nilai rata-rata sebesar 72,3\% dengan katergori baik, indikator media pembelajaran memiliki nilai rata-rata sebesar $77,7 \%$ dengan katergori sangat baik dan indikator evaluasi hasil belajar dengan nilai rata-rata sebesar 78,8 dengan kategori sangat baik. Berdasarkan deskripsi kategori nilai indikator variabel kompetensi guru yang wujudnya dalam bentuk pembuatan dokumen pembelajaran (RRP) di atas dapat disimpulkan bahwa indikator yang paling dominan dalam variabel kompetensi guru adalah evaluasi pembelajaran karena memiliki skor nilai yang sangat tinggi yaitu $77,8 \%$. Adapun rata-rata kompetensi guru SMK kabupaten Sumba Barat adalah $74,1 \%$ dengan kategori baik.

\section{Variabel Kinerja Guru}

Dapat diketahui bahwa pada indikator Penyusunan Program Pengajaran memiliki nilai rata-rata sebesar $79,2 \%$ dikategorikan mempunyai sangat baik, indikator Pelaksanaan Program Pembelajaran mempunyai nilai rata-rata sebesar $78,1 \%$ yang dikategorikan sangat baik dan indikator Pelaksanaan Evaluasi Pembelajaran mempunyai nilai rata-rata sebesar $80,3 \%$ dengan katergori sangat baik. Berdasarkan deskripsi kategori nilai indikator variabel Kinerja Guru (Y) di atas dapat disimpulkan bahwa indikator yang paling dominan dalam variabel Kinerja Guru adalah pelaksanaan evaluasi pembelajaran karena memiliki skor nilai yang sangat tinggi yaitu $80,3 \%$ dengan kategori sangat baik. Adapun rata-rata kinerja guru SMK di Kabupeten Sumba Barat adalah sebesar $79,2 \%$ dengan kategori sangat baik.

Dari 65 sampel diketahui bahwa yang berkinerja sangat baik 45 orang $(69.2 \%)$, sedangkan guru yang memiliki kinerja yang baik ada 10 orang (15.4\%), dan yang memiki kinerja cukup ada 7 orang (15.4\%), dan sisanya hanya ada 3 orang (4.6\%) guru yang memiliki kinerja yang buruk. 


\section{Hasil Uji Klasik}

Dapat dilihat bahwa nilai siginifikansi hasil uji normalitas sebesar 0,354 yang artinya nilai signifikansinya $>0,05$, sehingga $\mathrm{H}_{0}$ diterima dan dapat disimpulkan bahwa residual berdistribusi normal

1. Uji Multikolinieritas

Dapat diketahui bahwa variabel Kesejahteraan guru, Motivasi Kerja dan Kompetensi Guru masing-masing mempunyai nilai VIF sebesar 1,232; 1,004; dan 1,320 yang mana nilai-nilai tersebut $<10$, sehingga dapat disimpulkan bahwa diantara ketiga variabel bebas tersebut tidak terjadi multikolinieritas sehingga data dapat digunakan sebagai alat penelitian.

2. Uji Heterokedastisitas

Berdasarkan tabel 4.18 di atas dapat diketahui dari hasil uji Glejser masing-masing variabel independent memiliki nilai sig lebih besar dari 0,05 yang berarti terima $\mathrm{H}_{0}$ atau tidak terjadi Heteroskedastisitas. Jadi, model regresi linier berganda terbebas dari asumsi klasik heteroskedastisitas dan layak digunakan dalam penelitian.

\section{Pengujian Regresi Linier Berganda}

Analisis data yang digunakan dalam penelitian ini adalah regresi linear berganda yang digunakan untuk mengetahui ada tidaknya pengaruh Kesejahteraan Guru $\left(X_{1}\right)$, Motivasi Kerja $\left(\mathrm{X}_{2}\right)$, dan Kompetensi Guru $\left(\mathrm{X}_{3}\right)$ terhadap Kinerja Guru (Y). Diperoleh persamaan regresi linier berganda yang signifikan sebagai berikut :

$$
Y=0.143+0.317+0.248+0.519
$$

$\boldsymbol{Y}=$ Kinerja Guru

$\boldsymbol{a}=$ Koofisien regresi $(0.143)$

$X_{1}=$ Kesejahteran Guru $(0,317)$

$X_{2}=$ Motivasi Kerja $(0,248)$

$X_{3}=$ Kompetensi Guru $(0,519)$

Dari persamaan regresi diatas dapat ditarik kesimpulan sebagai berikut :

a. Nilai konstanta $\left(\beta_{0}\right)$ akan bernilai sama dengan nilai Kinerja Guru ( $Y$ ) sebesar 0,143 jika Kesejahteraan Guru $\left(\mathrm{X}_{1}\right)$, Motivasi Kerja
$\left(\mathrm{X}_{2}\right)$, dan Kompetensi Guru $\left(\mathrm{X}_{3}\right)$ bernilai konstan atau sama dengan nol.

b. Nilai koefisien Kesejahteraan Guru $\left(\beta_{1}\right)$ sebesar 0,317 menunjukkan bahwa jika variabel Kesejahteraan Guru $\left(X_{1}\right)$ naik satu satuan, maka akan mengakibatkan peningkatan Kinerja Guru sebesar 0,317. dan diasumsikan untuk variabel Motivasi kerja dan kompetensi guru konstan atau bernilai sama dengan nol.

c. Nilai koefisien Motivasi Kerja $\left(\beta_{2}\right)$ sebesar 0,248 menunjukkan bahwa jika variabel Motivasi kerja $\left(\mathrm{X}_{2}\right)$ naik satu satuan, maka akan mengakibatkan penurunan Kinerja Guru sebesar 0,248 dan diasumsikan untuk variabel Kesejahteraan Guru dan Kompetensi Guru konstan atau bernilai sama dengan nol.

d. Nilai koefisien Kompetensi Guru $\left(\beta_{3}\right)$ sebesar 0,519 menunjukkan bahwa jika variabel Kompetensi Guru $\left(\mathrm{X}_{3}\right)$ naik satu satuan, maka akan mengakibatkan peningkatan Kinerja Guru sebesar 0,519 dengan asumsi variabel Kesejahteraan Guru dan Motivasi kerja konstan atau bernilai sama dengan nol.

\section{PEMBAHASAN}

Tabel 1 Hasil Pengujian Hipotesis

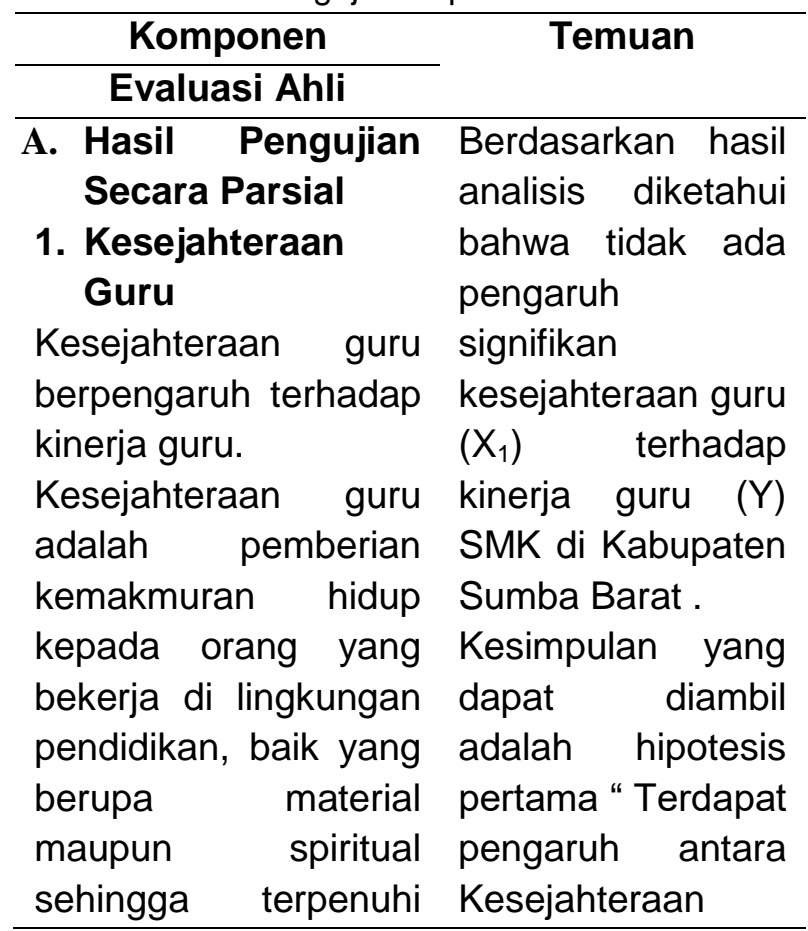




\begin{tabular}{|c|c|}
\hline $\begin{array}{l}\text { kehidupan yang layak } \\
\text { dan lebih baik sebagai } \\
\text { timbal balik atau balas } \\
\text { jasa dari tanggung } \\
\text { jawab yang } \\
\text { dipikulnya.Pemenuhan } \\
\text { kesejahteraan yang } \\
\text { memadai bagi guru } \\
\text { akan menambah } \\
\text { semangat dalam } \\
\text { pekerjaannya, } \\
\text { sehingga } \\
\text { kesadaran } \\
\text { mengembangkan dan } \\
\text { meningkakan kualitas } \\
\text { sumber daya yang } \\
\text { ada pada dirinya( } \\
\text { Samana, 1994:15). }\end{array}$ & 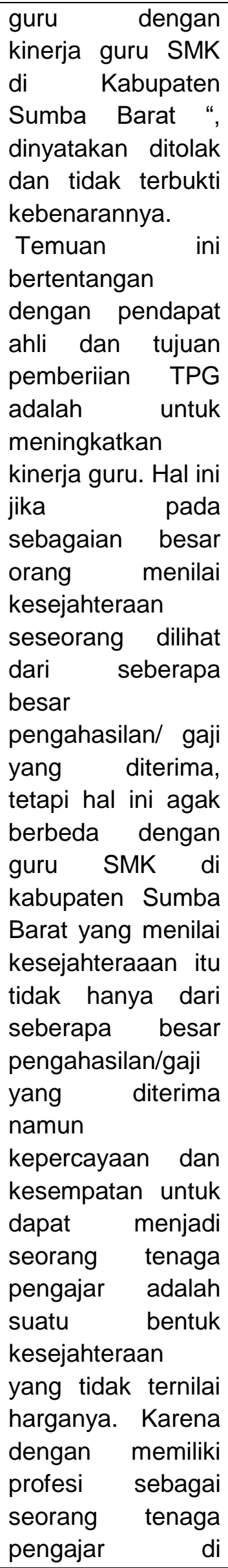 \\
\hline
\end{tabular}

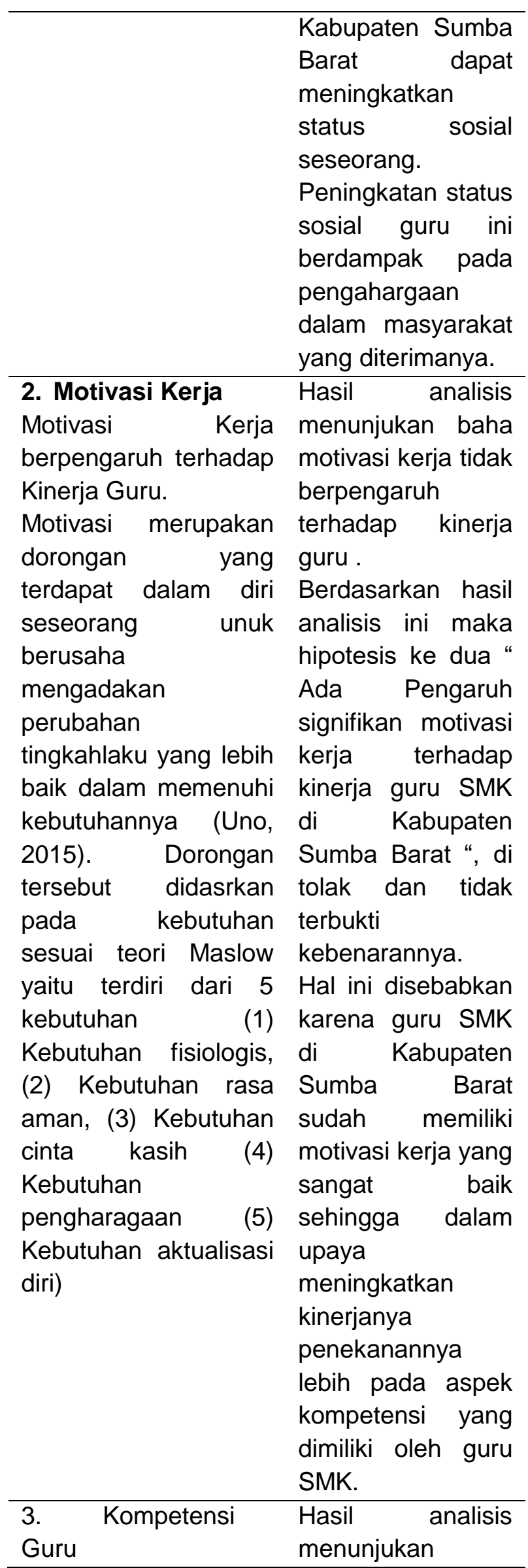




\begin{tabular}{|c|c|}
\hline 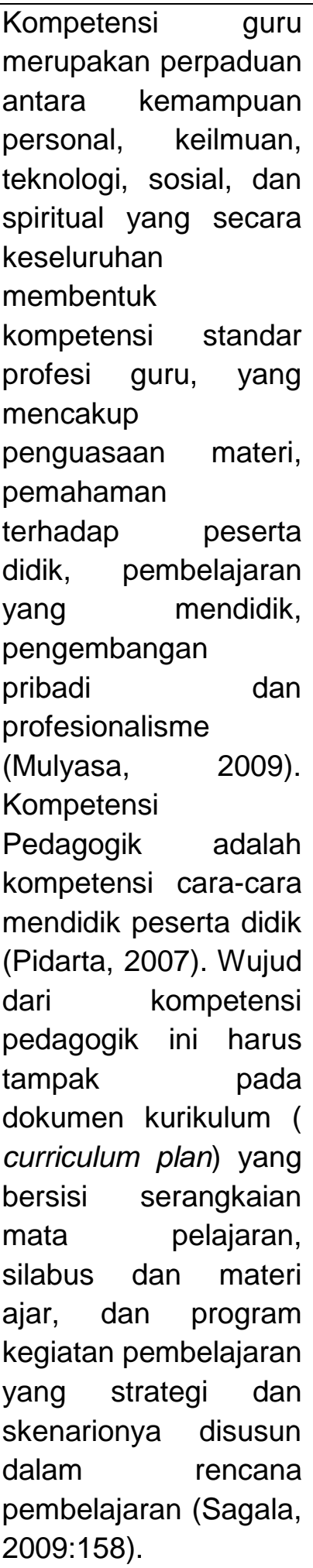 & 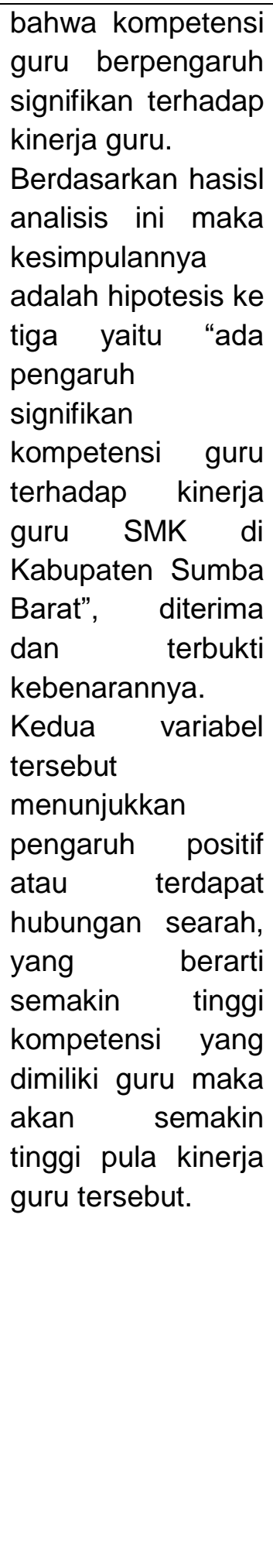 \\
\hline
\end{tabular}

\begin{tabular}{lrlr}
\hline B. Hasil & Pengujian & Hasil analisis \\
\multicolumn{2}{c}{ Secara Simultan } & menunjukkan \\
Kinerja & guru & variabel \\
dipengruhi & oleh & Kesejahteraan \\
beberapa & faktor & Guru $\left(\mathrm{X}_{1}\right)$, Motivasi \\
diantaranya & adalah & Guru $\left(\mathrm{X}_{2}\right)$, dan \\
kesejahteraan & guru, & Kompetensi & Guru \\
\hline
\end{tabular}

\begin{tabular}{|c|c|}
\hline $\begin{array}{l}\text { motivasi kerja dan } \\
\text { kompetensi guru }\end{array}$ & 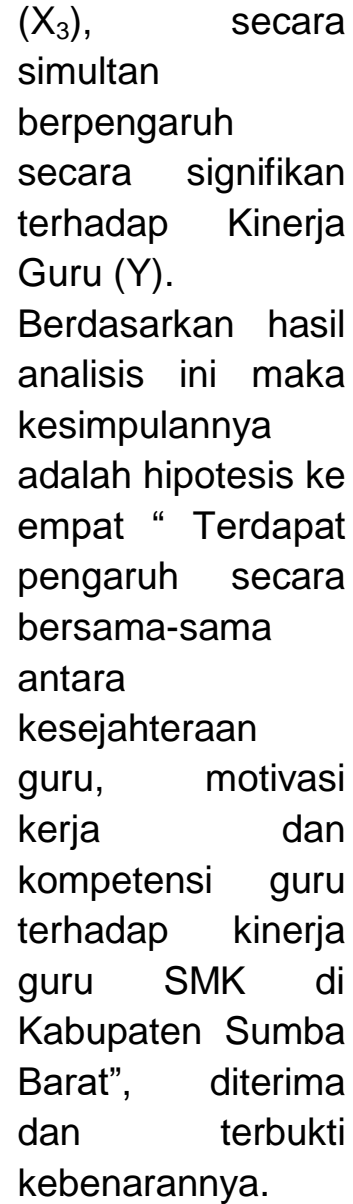 \\
\hline
\end{tabular}

\section{KESIMPULAN}

Berdasarkan hasil analisis data dan pembahasan pada bab sebelumnya dengan menggunakan analisis regresi berganda maka dapat ditarik simpulan sebagai berikut :

1. Tidak ada pengaruh antara kesejahteraan guru terhadap kinerja guru SMK di Kabupaten Sumba Barat, karena guru SMK dikabupetan Sumba Barat tidak menilai kesejahteraan dari sisi besarnya gaji/imbalan jasa yang diterima.

2. Tidak ada pengaruh antara motivasi kerja dengan kinerja guru SMK di Kabupaten Sumba Barat. Semangat pengabdian yang tinggi merupakan salah satu faktor yang menunjang kinerja guru.

3. Ada pengaruh antara kompetensi guru dengan kinerja guru SMK di Kabupaten Sumba Barat . Semakin tinggi kompetensi seseorang maka kinerja guru akan semakin tinggi, namun sebaliknya jika semakin rendah kompetensi seseorang maka kinerja guru akan rendah. 
4. Ada pengaruh secara bersama-sama antara kesejahteraan guru, motivasi kerja dan kompetensi guru terhadap kinerja guru SMK di Kabupaten Sumba Barat. Dalam rangka meningkatkan kinerja guru SMK di kabupaten Sumba Barat maka perlu aanya peningkatan kesejahteraan guru, motivasi kerja dan kompetensi guru.

\section{DAFTAR PUSTAKA}

Arikunto, Suharsimi, (2010). Prosedur Penelitian Suatu Pendekatan Praktik. Jakarta : Rineka Cipta.

Bok, H. G. J., Teunissen, P. W., Favier, R. P., Rietbroek, N. J., Theyse, L. F. H., Brommer, H., ... Jaarsma, D. A. D. C. (2013). Programmatic assessment of competency-based workplace learning : when theory meets practice. 1-9.

Cahyana, A. (2006). Pengembangan Kompetensi Profesional Guru Dalam Menghadapi Sertifikasi. 85-91.

Canrinus, E. T., \& Helms-lorenz, M. (2012). Self-efficacy, job satisfaction, motivation and commitment : exploring the relationships between indicators of teachers 'professional identity. 115-132. https://doi.org/10.1007/s10212-011-00692

Dharma, Surya. (2008). Manajemen Kinerja, Falsa/ah, Teori dan Penerapannya. Yogyakarta : Pustaka Pelajar.

Djatmiko, E. (2006). Pengaruh Kepemimpinan Kepala Sekolah dan Sarana Prasarana terhadap Kinerja Guru SMP Negeri Kota Semarang (The Effect of the Principal's Leadership and Facilities on the Teacher's Performance of State Junior High Schools of Semarang Municipality). Fokus Ekonomi, 1(2), 19-30.

Hornstra, L., Mansfield, C., \& Veen, I. Van Der. (2015). and contextual factors. Learning Environments Research, 18(3), 363-392. https://doi.org/10.1007/s10984-015-9189$\mathrm{y}$

Jayapura, D. I. K. (2013). JURNAL ILMU PENDIDIKAN INDONESIA.

Kebijakan, P. P., Kemdikbud, B., Lantai, G. E., Jenderal, J., \& Jakarta, S. S.-. (2013). Tingkat Ketidakhadiran Guru Sekolah
Dasar Dan ( Teacher Absenteeism Study On Primary School And lts Impact On Student) Status kepegawaian : Pegawai negeri sipil Guru kontrak Peran : Kepala sekolah. 31-49.

Khodijah, N. (2009). Kinerja Guru Madrasah dan Guru Pendidikan Agama Islam Pasca Sertifikasi Di Sumatera Selatan. Cakrawala Pendidikan, 1, 91-202.

Li, H. (2014). Compensation of Chinese early childhood teachers : a preliminary study in Hong Kong ,. 1-14.

Matematika, G., \& Dan, S. M. P. (2014). Jurnal Riset Pendidikan Matematika, Volume 1 - Nomor 2, November 2014. 1(November), 284-296.

Maulana, R., Yulia, M. H., \& Wim, I. (2016). Autonomous Motivation in the Indonesian Classroom : Relationship with Teacher Support Through the Lens of Self- Determination Theory. The Asia-Pacific Education Researcher, 25(3), 441-451. https://doi.org/10.1007/s40299-0160282-5

Mulyasa. (2009). Standar kompetensi dan Sertifikasi Guru. Bandung : Remaja Rosdakarya.

Nawawi, Hadari. (2004). Manajemen Sumber Daya Manusia. Yogyakarta. Gajah Mada University Pres.

Peraturan Pemerintah Republik Indonesia No. 74 tahun 2008. Tentang guru.

Pidarta, Made. (2007) Wawasan Pendidikan. Surabaya: Unesa Universiti Press.

Roermund, T. C. M. Van, Tromp, F., Scherpbier, A. J. J. A., Bottema, B. J. A. M., \& Bueving, H. J. (2011). Teachers 'ideas versus experts' descriptions of 'the good teacher' in postgraduate medical education : implications for implementation. A qualitative study.

Rotthoff, T., Ostapczuk, M. S., Bruin, J. De, Kröncke, K., Decking, U., Schneider, M., \& Ritz-timme, S. (2012). Development and evaluation of a questionnaire to measure the perceived implementation of the 
mission statement of a competency based curriculum.

Sagala, Syaiful. (2006). Administrasi Pendidikan Kontemporer. Bandung: Alfabeta.

Samana, A. 1994. Profenalisme Keguruan. Yogyakarta. Hikayat, Cetakan I.

Samani, Muchlas, dkk. (2006). Mengenal Sertifikasi Guru di Indonesia. Madiun . SIC

Setelah, D., Tunjangan, M., \& Guru, P. (2012). Journal of Educational Social Studies. 1(1).

Soewarno, S., \& Fitri, Z. (n.d.). Evaluasi kinerja guru fisika, biologi dan kimia sma yang sudah lulus sertifikasi. (3).

Spilt, J. L., Koomen, H. M. Y., \& Thijs, J. T. (2011). Teacher Wellbeing: The Importance of Teacher - Student Relationships. 457-477. https://doi.org/10.1007/s10648-011-9170$\mathrm{y}$

Sullivan, P. S. O. (2015). What 's in a learning environment? Recognizing teachers ' roles in shaping a learning environment to support competency. 277-279. https://doi.org/10.1007/s40037-015-02344

Yu, K. (2013). Motivations for choosing teaching as a career: a perspective of pre-service teachers from a Turkish context. 295-306. https://doi.org/10.1007/s12564-013-92589

Yusta, T., \& Pradata, W. (2015). Evalusi Program Wajib Belajar 12 Tahun Pada Masyrakat Miskin Di Kelurahan Wonokusumo Kecamatan Semampir. 3, 176-185. 